\title{
Phylogenetic and taxonomic status of the coral Goniopora stokesi and related species (Scleractinia: Poritidae) in Japan based on molecular and morphological data
}

\author{
Yuko F Kitano ${ }^{1}$, Masami Obuchi ${ }^{2}$, Daisuke Uyeno ${ }^{3}$, Katsumi Miyazaki ${ }^{1}$ and Hironobu Fukami ${ }^{4^{*}}$
}

\begin{abstract}
Background: Goniopora stokesi is an uncommon species mainly found in tropical and subtropical regions but was also reported in temperate regions of Japan. This species has two unique characteristics. First, it does not typically attach to hard substrates, i.e., it is free-living. Although non-free-living colonies were reported, it is unclear whether their morphologies exhibit intraspecific or interspecific differences. Second, they can asexually form daughter colonies, which are secondary colonies that grow on the surface (coenosac) of a parent colony and subsequently detach. To date, this specific characteristic has not been reported in Japan, and it is not clear whether this species occurs in Japan.

Results: To clarify the taxonomic status of this species, we investigated its reproductive mechanism in Japan and morphologically and genetically analyzed specimens collected from both subtropical and temperate regions. We found that this species forms daughter colonies in Okinawa, Japan and that free-living colonies in the temperate region, which were formerly recognized as $G$. stokesi, likely constitute a morphological variation of a separate species. In addition, all non-free-living colonies with G. stokesi-like morphologies were also morphological variations of other species.

Conclusions: Overall, free-living colonies with large, deep calices, thin walls, and well-developed epitheca on the underside were G. stokesi, whereas other free-living and all non-free-living G. stokesi-like colonies belonged to other species, such as Goniopora djiboutiensis.
\end{abstract}

Keywords: Evolution; Phylogeny; rDNA; COl; Temperate region

\section{Background}

The genus Goniopora (Cnidaria: Scleractinia: Poritidae) is common throughout the Indo-Pacific, including tropical and temperate regions. However, there are very few ecological and molecular studies of Goniopora (e.g., Heyward 1985). Taxonomically, Goniopora is easily distinguished from confamilial genera such as Porites and Alveopora, by having three septal cycles (vs. two in Porites and Alveopora)

\footnotetext{
* Correspondence: hirofukami@cc.miyazaki-u.ac.jp

${ }^{4}$ Department of Marine Biology and Environmental Science, Faculty of Agriculture, University of Miyazaki, 1-1 Gakuen-kibanadai Nishi, Miyazaki 889-2192, Japan

Full list of author information is available at the end of the article
}

and relatively larger corallites (Veron and Pichon 1982). Also, Goniopora has a genus-specific septal formula (called 'the gonioporoid pattern'; Bernard 1903; Veron and Pichon 1982). In the field, Goniopora may be confused with Alveopora because the polyps of both genera have very long columns, although Veron and Pichon (1982) pointed out that Goniopora polyps have 24 tentacles, whereas Alveopora polyps have 12 . Despite the morphological similarities, the two genera are phylogenetically distant (Romano and Cairns 2000; Fukami et al. 2008).

Goniopora stokesi Milne Edwards and Haime, 1851 (Cnidaria: Scleractinia: Poritidae), which is widely distributed in subtropical and tropical regions from the Red Sea through the Indo-West Pacific, has the largest polyps 
of any species of the genus (Veron 2000). Based on descriptions of this species (Milne Edwards and Haime 1851; Milne Edwards 1860), the colony is hemispherical in shape, and calices are about $5 \mathrm{~mm}$ wide and $6 \mathrm{~mm}$ deep. The walls are very thin and porous with rugged tops. The underside of the corallum is covered by an epitheca, a thin layer of calcium carbonate. A notable characteristic of this species is that several daughter colonies (or polyp balls) are asexually formed from living tissues on the surface of the parental colony and are released around the parental colony (Scheer 1960; Rosen and Taylor 1969). This is a unique and peculiar reproductive mechanism among zooxanthellate scleractinian corals. In addition, unlike other species of the same genus, G. stokesi is typically found on soft substrates (e.g., mud or sand) and does not usually attach to hard substrates, i.e., it is free-living (Veron and Pichon 1982). This unique reproductive mechanism may be the result of adaptations to specific environmental conditions (Rosen and Taylor 1969).

However, some non-free-living colonies of G. stokesi were reported (Nemenzo 1955; Veron and Pichon 1982), which are difficult to distinguish from related species. According to Veron and Pichon (1982), G. stokesi is similar to Goniopora lobata Milne Edwards and Haime, 1851, Goniopora djiboutiensis Vaughan, 1907, and Goniopora columna Dana, 1846, all of which have corallites that are similar to G. stokesi in size and distribution patterns. In addition, Goniopora pendulus Veron, 1985, which is distributed only in the West Pacific (Veron 2000), is also morphologically similar to G. stokesi in the characters of the corallites and the size of the polyps (Veron 1985, 2000). Veron (2000) grouped three species (G. pendulus, G. djiboutiensis, and G. stokesi) into the same category, group 1, which represents massive species with large ( $>5 \mathrm{~mm}$ in diameter) corallites. Although G. lobata and G. columna were included in group 2, with branching or columnar species having large ( $>5 \mathrm{~mm}$ in diameter) corallites, the variation in the colony shape of these species was similar to that in G. djiboutiensis or G. stokesi (Veron and Pichon 1982). It is hard to define species boundaries among scleractinian corals because of the variability and size of morphological features of the skeleton. Species identification is therefore difficult because of a lack of characteristic morphological features. Thus, it remains unknown whether non-free-living colonies of G. stokesi truly represent intraspecific morphological variation or whether they belong to different species.

In Japan, G. stokesi was reported from subtropical regions of the Ryukyu Archipelago (Okinawa Prefecture), including Tanegashima Island (Kagoshima) (Veron 1992), and also from three temperate regions of Amakusa (Kumamoto), Tosashimizu (Kochi) (Veron 1992), and Miyake Island (Tokyo) (Tribble and Randall 1986). However, the unique asexual reproductive mechanism of forming daughter colonies has not yet been reported in Japan (Nishihira and Veron 1995). To the best of our knowledge, none of the skeletal samples used in those studies were stored in a known repository. It therefore remains unclear whether temperate colonies can be identified as G. stokesi and whether colonies in subtropical and temperate regions belong to the same species. In particular, the colony reported as G. stokesi by Nishihira and Veron (1995) appears to have much smaller calices than the typical colonies of G. stokesi. The possibility that some colonies identified as G. stokesi in Japan belong to different species cannot be excluded.

Recent molecular analyses have helped resolve several issues regarding coral taxa (e.g., phylogenetic positions and species boundaries) (Fukami et al. 2008; Forsman et al. 2009; Benzoni et al. 2010; Kitahara et al. 2010). In this study, we investigated G. stokesi and morphologically similar specimens collected from subtropical and temperate Japan using molecular and skeletal morphological analyses to clarify its phylogenetic and taxonomic status in Japan.

\section{Methods \\ Sampling}

Samples were collected from eight subtropical and six temperate sites. The subtropical sites were Iriomote Island (IR), Ishigaki and Taketomi Islands (IS), Oura Bay (OU), Sesoko Island (SS), Nakijin (NK), Kikai Island (KK), Amami-Oshima Island (AO), and Tanegashima Island (TN); while temperate sites were Amakusa (AM), Miyazaki-Oshima (MO), Otsuski (OT), Yokonami (YO), Shirahama (SR), and Kushimoto (KS) (Figure 1). We surveyed all localities where G. stokesi was previously recorded (see 'Background'), excluding Tosashimizu and Miyake Island, although Tosashimizu is geographically close $(20 \mathrm{~km})$ to Otsuki (Figure 1). Sampling was performed by scuba diving (two to more than ten occasions per site, at depths of 5 to $30 \mathrm{~m}$ ). We selected massive colonies with large corallites (approximately $5 \mathrm{~mm}$ in diameter), but we did not identify them in the field because it is difficult to identify species from living colonies. During sampling, we took photographs of the living colonies. Samples $\left(100\right.$ to $500 \mathrm{~cm}^{3}$ ) were collected using hammer and chisel. A portion of each sample $\left(<1 \mathrm{~cm}^{3}\right)$ was maintained in CHAOS solution (Fukami et al. 2004) to dissolve proteins for DNA analyses, and the remnants of the samples were bleached for morphological analyses.

\section{Species identification}

Species identification of Goniopora is difficult because of the limited number of skeletal characters and highly variable skeletal and polyp morphologies. To minimize the risk of misidentification in this study, we examined and summarized (data not shown) the original descriptions (for all species listed in this study) and related references 


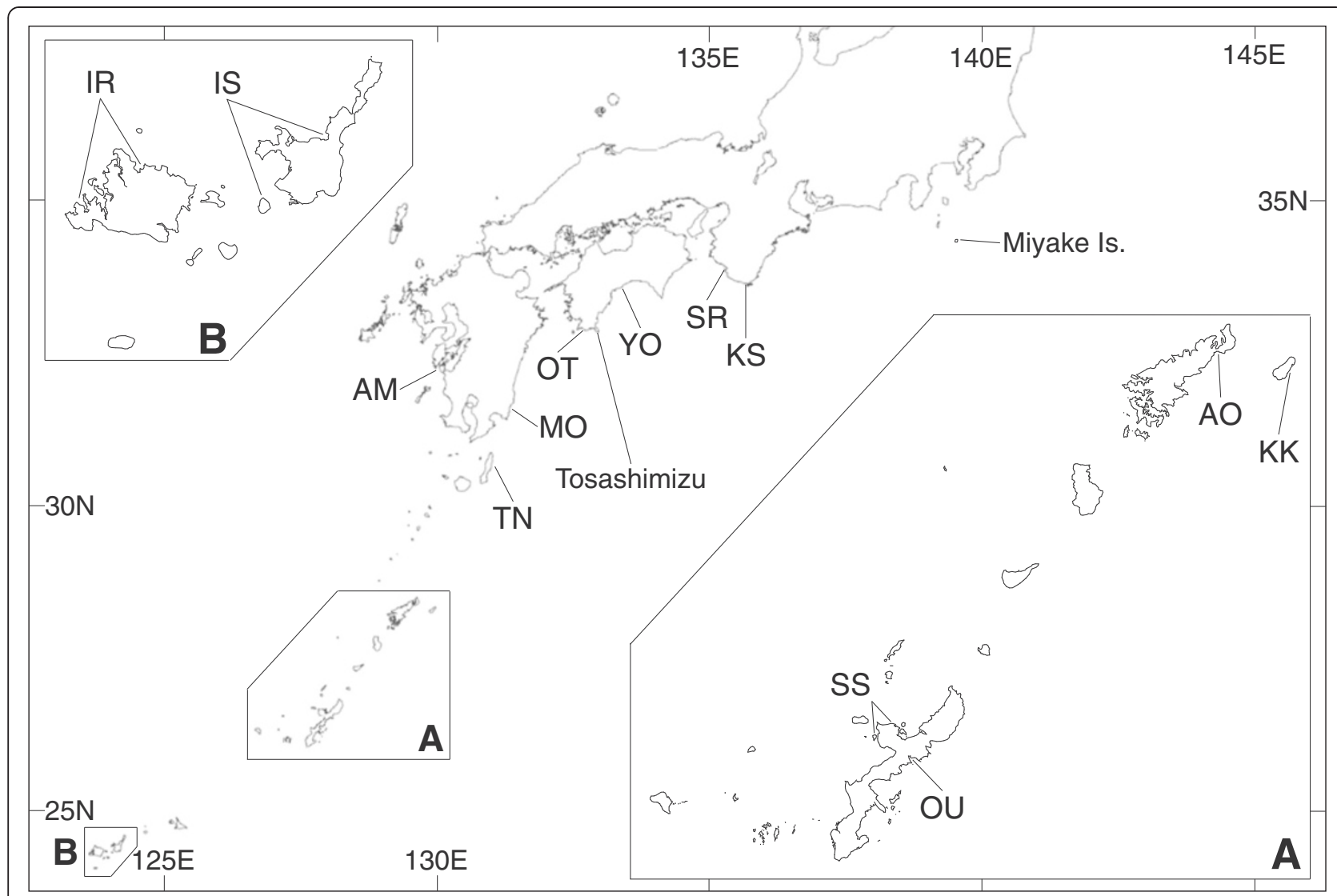

Figure 1 Sampling sites in Japan. Iriomote Island (IR), Ishigaki and Taketomi Islands (IS), Oura Bay (OU), Sesoko Island (SS), Nakijin (NK), Kikai Island (KK), Amami-Oshima Island (AO), Tanegashima Island (TN), Amakusa (AM), Miyazaki-Oshima (MO), Otsuski (OT), Yokonami (YO), Shirahama (SR), and Kushimoto (KS).

(Milne Edwards and Haime 1851; Milne Edwards 1860; Ortmann 1888; Bernard 1903; Bedot 1907; Vaughan 1907; Faustino 1927; Crossland 1952; Nemenzo 1955; Wells 1955; Veron and Pichon 1982; Veron 1985, 2000; Nishihira and Veron 1995). Specimens identified in this study are referred to as morphospecies (Oliver and Beattie 1996). Traditionally, species identification of Goniopora is based on skeletal characters such as the shapes of the coralla, septa, columella, and wall, and the size of the calices; but recently, Veron and Pichon (1982), Nishihira and Veron (1995), and Veron (2000) added polyp characters to support species identification.

\section{Molecular analyses}

Total DNA was extracted from coral tissue dissolved in CHAOS solution using a phenol/chloroform extraction method (see Fukami et al. 2004). Mitochondrial (mt)DNA sequences between the end of NADH dehydrogenase subunit 5 (ND5) and the first half of cytochrome oxidase subunit I (COI), including three intergenetic regions (IGRs), tRNA $^{\text {Trp }}$, and ATPase 8 were amplified using a polymerase chain reaction (PCR) with the primers ZCO1 and ZCO1R for the COI segment (Forsman et al. 2009) and Cs-F15 and
Cs-R15 for the other segments (Lin et al. 2011). Because ND5 and COI were the primary components of the DNA sequences, we refer to them as ND5-COI in this study. Internal transcribed spacers (ITSs) of the nuclear ribosomal DNA (including partial 18S, ITS-1, 5.8S, ITS-2, and partial 28S) were also amplified by the PCR using primers $1 S$ and 2SS (Wei et al. 2006). PCR conditions for these two markers were $94^{\circ} \mathrm{C}$ for $30 \mathrm{~s}$ followed by 30 or 35 cycles at $94^{\circ} \mathrm{C}$ for $30 \mathrm{~s}, 55$ or $60^{\circ} \mathrm{C}$ for $45 \mathrm{~s}$, and $72^{\circ} \mathrm{C}$ for $90 \mathrm{~s}$, with a final phase of $72^{\circ} \mathrm{C}$ for $5 \mathrm{~min}$. For the mitochondrial region, $\mathrm{PCR}$ products were treated with shrimp alkaline phosphatase and exonuclease I at $37^{\circ} \mathrm{C}$ for $40 \mathrm{~min}$ followed by $80^{\circ} \mathrm{C}$ for $20 \mathrm{~min}$. Then the DNA sequences were determined by direct sequencing using ABI3730 or ABI310 sequencers (Applied Biosystems, Alameda, CA, USA). PCR products of the nuclear marker were also directly sequenced, but when they obtained sequences had double peaks in the chromatogram, they were subcloned into the TA vector (Promega, Madison, WI, USA) or TOPO10 (Invitrogen, Grand I., NY, USA) and were sequenced using ABI3730 or ABI310. All DNA sequences obtained in this study were submitted to DDBJ (accession numbers AB748660-AB748793 and AB764138, as listed in Table 1). 
Table 1 List of identification of species of Goniopora based on the literature and the accession numbers of DNA sequences

\begin{tabular}{|c|c|c|c|c|c|c|c|c|}
\hline \multirow[t]{2}{*}{ Species } & \multirow{2}{*}{$\begin{array}{l}\text { Morphological } \\
\text { features for 'cf' }\end{array}$} & \multirow[t]{2}{*}{ Sample number } & \multirow[t]{2}{*}{ Location } & \multicolumn{2}{|c|}{ Accession number } & \multirow[t]{2}{*}{ Measurement } & \multirow[t]{2}{*}{ Free-living } & \multirow{2}{*}{$\begin{array}{l}\text { Developmen } \\
\text { of epitheca }\end{array}$} \\
\hline & & & & rDNA & mtDNA & & & \\
\hline G. columna & & 153 & Ishigaki & $A B 748660$ & & & & \\
\hline G. columna & & IS4 & Ishigaki & AB748661 & AB748754 & & & \\
\hline G. columna & & IR29 & Iriomote & & $A B 764138$ & & & \\
\hline S. stokesi & & NK1 & Nakijin & AB748662 & AB748755 & Yes & Yes & Yes \\
\hline G. stokesi & & OU12 & Oura Bay & AB748663 & AB748756 & & Yes & Yes \\
\hline G. stokesi & & OU14 & Oura Bay & AB748664 & & & Yes & Yes \\
\hline G. stokesi & & OU17 & Oura Bay & AB748665 & AB748757 & & Yes & Yes \\
\hline G. stokesi & & OU19 & Oura Bay & AB748666 & AB748758 & & Yes & Yes \\
\hline G. stokesi & & OU20 & Oura Bay & AB748667 & $A B 748759$ & Yes & Yes & Yes \\
\hline G. stokesi & & OU22 & Oura Bay & AB748668 & & & Yes & Yes \\
\hline G. stokesi & & OU24 & Oura Bay & AB748669 & $A B 748760$ & & Yes & Yes \\
\hline G. stokesi & & OU26 & Oura Bay & AB748670 & & & Yes & Yes \\
\hline G. stokesi & & OU41 & Oura Bay & AB748671 & & & Yes & Yes \\
\hline G. stokesi & & OU43 & Oura Bay & AB748672 & $A B 748761$ & Yes & Yes & Yes \\
\hline G. stokesi & & IR27 & Iriomote & AB748673-4 & AB748762 & Yes & Yes & \\
\hline G. stokesi & & IR65 & Iriomote & AB748675 & AB748763 & Yes & Yes & Yes \\
\hline G. cf. stokesi & $\begin{array}{l}\text { Shallow calices, colony } \\
\text { attached to substrate }\end{array}$ & M082 & Miyazaki & AB748686 & AB748768 & Yes & & \\
\hline G. lobata & & $\mathrm{KS} 28$ & Kushimoto & AB748741 & AB748788 & Yes & & \\
\hline G. lobata & & KS57 & Kushimoto & AB748742 & & & & \\
\hline G. lobata & & SR44 & Shirahama & AB748743 & & & & \\
\hline G. lobata & & YO1 & Yokonami & AB748744 & AB748789 & Yes & & \\
\hline G. lobata & & Y010 & Yokonami & $A B 748745-6$ & & & & \\
\hline G. lobata & & MO36 & Miyazaki & $A B 748747-8$ & AB748790 & Yes & & \\
\hline G. lobata & & AM48 & Amakusa & AB748749 & & & & \\
\hline G. lobata & & IR42 & Iriomote & AB748750 & AB748791 & Yes & & \\
\hline G. cf. lobata & With pali & SR14 & Shirahama & AB748751 & AB748792 & Yes & & \\
\hline G. cf. lobata & With pali & $\mathrm{AO} 58$ & Amami & AB748752 & AB748793 & Yes & & \\
\hline G. cf. lobata & Wide columella & M067 & Miyazaki & AB748687 & AB748769 & Yes & & \\
\hline G. cf. lobata & Wide columella & IS20 & Taketomi & AB748753 & & Yes & & \\
\hline G. djiboutiensis & & KS9 & Kushimoto & AB748695 & & & & \\
\hline G. djiboutiensis & & SR62 & Shirahama & AB748696 & & & & \\
\hline G. djiboutiensis & & ОT30 & Otsuki & AB748697 & AB748775 & Yes & & \\
\hline G. djiboutiensis & & AM30 & Amakusa & AB748698 & & & & \\
\hline G. djiboutiensis & & AM74 & Amakusa & AB748699 & AB748776 & Yes & Yes & \\
\hline G. djiboutiensis & & KK16 & Kikai & AB748700 & & & & \\
\hline G. djiboutiensis & & KK60 & Kikai & AB748701 & & & & \\
\hline G. djiboutiensis & & SS35 & Sesoko & AB748702 & AB748777 & Yes & & \\
\hline G. djiboutiensis & & OU2 & Oura Bay & AB748703 & & & & \\
\hline G. djiboutiensis & & OU7 & Oura Bay & AB748704 & & & & \\
\hline G. djiboutiensis & & OU21 & Oura Bay & AB748705 & AB748778 & Yes & & \\
\hline
\end{tabular}




\section{Table 1 List of identification of species of Goniopora based on the literature and the accession numbers of DNA} sequences (Continued)

\begin{tabular}{|c|c|c|c|c|c|c|c|}
\hline \multicolumn{2}{|l|}{ G. djiboutiensis } & OU28 & Oura Bay & AB748706 & & & \\
\hline \multicolumn{2}{|l|}{ G. djiboutiensis } & OU33 & Oura Bay & AB748707 & & & \\
\hline \multicolumn{2}{|l|}{ G. djiboutiensis } & IR13 & Iriomote & $A B 748708-9$ & & & \\
\hline \multicolumn{2}{|l|}{ G. djiboutiensis } & IR22 & Iriomote & $A B 748710-1$ & AB748779 & Yes & \\
\hline \multicolumn{2}{|l|}{ G. djiboutiensis } & IR67 & Iriomote & AB748712 & AB748780 & & \\
\hline G. cf. djiboutiensis & Small columella & KS31 & Kushimoto & AB748713 & & & \\
\hline G. cf. djiboutiensis & Small columella & KS51 & Kushimoto & $A B 748714$ & & & \\
\hline G. cf. djiboutiensis & No pali, small calice & SR23 & Shirahama & $A B 748715-6$ & & & \\
\hline G. cf. djiboutiensis & Deep calice & SR24 & Shirahama & $A B 748717$ & & & \\
\hline G. cf. djiboutiensis & $\begin{array}{l}\text { Irregular shape } \\
\text { of corallum }\end{array}$ & ОT24 & Otsuki & AB748688 & $A B 748770$ & Yes & \\
\hline G. cf. djiboutiensis & Deep calice & OT29 & Otsuki & AB748718-20 & AB748781 & Yes & \\
\hline G. cf. djiboutiensis & Deep calice & MO16 & Miyazaki & AB748721 & & & \\
\hline G. cf. djiboutiensis & Deep calice & $\mathrm{MO} 23$ & Miyazaki & AB748689 & AB748774 & Yes & \\
\hline G. cf. djiboutiensis & Deep calice & MO40 & Miyazaki & AB748722 & & & \\
\hline G. cf. djiboutiensis & Deep calice & MO53 & Miyazaki & AB748723 & AB748782 & Yes & \\
\hline G. cf. djiboutiensis & Deep calice & MO63 & Miyazaki & $A B 748724-5$ & & & \\
\hline G. cf. djiboutiensis & Thin wall & AM26 & Amakusa & $A B 748726-7$ & & & \\
\hline G. cf. djiboutiensis & $\begin{array}{l}\text { Irregular shape } \\
\text { of corallum }\end{array}$ & AM75 & Amakusa & AB748728-9 & AB748783 & Yes & Yes \\
\hline G. cf. djiboutiensis & Small, deep calice & AM89 & Amakusa & $A B 748730$ & AB748784 & Yes & Yes \\
\hline G. cf. djiboutiensis & Thin wall & TN40 & Tanegashima & $A B 748731-2$ & & & \\
\hline G. cf. djiboutiensis & No pali & TN41 & Tanegashima & AB748690 & AB748771 & Yes & \\
\hline G. cf. djiboutiensis & No pali & TN55 & Tanegashima & AB748733-4 & AB748785 & & \\
\hline G. cf. djiboutiensis & No pali & TN95 & Tanegashima & AB748735 & AB748786 & Yes & \\
\hline G. cf. djiboutiensis & No pali & TN113 & Tanegashima & AB748736 & AB748787 & Yes & \\
\hline G. cf. djiboutiensis & Small columella & TN115 & Tanegashima & AB748737-8 & & & \\
\hline G. cf. djiboutiensis & Deep calice & KK4 & Kikai & AB748691 & AB748772 & & \\
\hline G. cf. djiboutiensis & No pali & KK11 & Kikai & AB748692 & AB748773 & Yes & \\
\hline G. cf. djiboutiensis & No pali & KK22 & Kikai & AB748693 & & & \\
\hline G. cf. djiboutiensis & No pali & KK27 & Kikai & AB748694 & & & \\
\hline G. cf. djiboutiensis & $\begin{array}{l}\text { Deep calice at } \\
\text { top of colony }\end{array}$ & IS19 & Taketomi & AB748739 & & & \\
\hline G. cf. djiboutiensis & $\begin{array}{l}\text { Deep calice at } \\
\text { top of colony }\end{array}$ & IR3 & Iriomote & AB748740 & & & \\
\hline G. pendulus & & OT14 & Otsuki & AB748676-80 & AB748764 & Yes & \\
\hline G. pendulus & & OT19 & Otsuki & AB748681 & $A B 748765$ & Yes & \\
\hline G. pendulus & & ОT27 & Otsuki & AB748682 & & & \\
\hline G. pendulus & & OT31 & Otsuki & AB748683 & AB748766 & Yes & \\
\hline G. pendulus & & TN11 & Tanegashima & AB748684 & AB748767 & Yes & \\
\hline G. pendulus & & TN42 & Tanegashima & AB748685 & & & \\
\hline
\end{tabular}

For outgroups, we used two colonies of G. columna, the corallites which are similar in size to those of $G$. djiboutiensis and G. lobata but which forms thick branches or short columns, because our preliminary data showed that this species was genetically distant from other species analyzed in the study.

DNA sequences were aligned with Sequencher version 5.1 (Gene Codes, Ann Arbor, MI, USA) and SeaView 
version 4.3.0 (Gouy et al. 2010). Phylogenetic trees were reconstructed using the neighbor-joining (NJ), maximumlikelihood (ML), and Bayesian-inference (BI) techniques. For the NJ, ML, and BI methods, we assumed a model of nucleotide evolution obtained using the Akaike information criterion (AIC) as implemented in MrModeltest 2.2 (Nylander 2004). The most appropriate models of nucleotide evolution were K81 (Kimura 3-parameter model) with unequal base frequencies (K81uf) for the ND5-COI marker and TVM with equal base frequencies (TVMef) for the ITS markers. For NJ, PAUP* (Swofford 2002) was used to estimate the topologies for both the ND5-COI and ITS markers and conduct a bootstrap analysis (with 1,000 replicates). PAUP was also used to reconstruct the best ML tree using a heuristic search and the tree-bisection-reconnection branch-swapping method for each marker. The software, GARLI version 0.951 (Zwickl 2006), was used to search for optimal ML topologies and conduct bootstrap analyses (500 replicates) for each marker. MrBayes 3.1.2 (Ronquist and Huelsenbeck 2003) was also used to conduct Bayesian analyses. Four parallel chains of $4 \times 10^{6}$ to $5 \times 10^{6}$ generations were run for each marker. Trees were sampled every 100 generations, and $10^{4}$ 'burn-in' trees were excluded from the consensus tree. The average standard deviation of split frequencies after $4 \times 10^{6}$ generations was 0.002069 for ND5-COI, and after $5 \times 10^{6}$ generations was 0.013847 for ITS. Because parsimoniously informative sites (13 characters) of ND5COI were fewer than those (83 characters) of the ITS, we analyzed more samples for ITS to infer clearer phylogenetic relationships.

\section{Morphological analyses}

The skeletal morphology of each specimen was examined using a VHX-1000 digital microscope (Keyence, Osaka, Japan) to measure diameters of both the columella and calice, and using vernier calipers to measure the depth of the calice and thickness of the walls. Columella and calice diameters, the depth of the calice, the width of the walls, the number of septa, development of the pali, and the septal arrangement (presence of a gonioporoid pattern), all of which were evaluated from 5 mature corallites per colony (excluding those near the edge of a colony, which tended to be deformed), were measured or counted (Figure 2). For development of pali, we classified them into three categories: $\geq 6$ pali, 1 to 5 pali, and no pali. For the septal arrangement, we also classified them in three categories: a clear gonioporoid pattern, an irregular (imperfect) gonioporoid pattern, and no gonioporoid pattern. For columella $(\mathrm{Co})$ and calice $(\mathrm{Ca})$ diameters, we measured the longest diameter (long diameter, L) and the dimension orthogonal to the longest diameter (short diameter, S) (referred to as LCo, LCa, SCo, and $\mathrm{SCa}$, respectively) (Figure $2 \mathrm{~A}$ ). In addition, ratios of $\mathrm{S} / \mathrm{L}$ of the columella and calice (SCo/LCo, SCa/LCa) and the columella/calice ratio using the $\mathrm{L}(\mathrm{LCo} / \mathrm{LCa})$ were calculated. For calice depth (DC) and wall thickness (TW), we measured three different parts for each corallite (Figure 2B), and the calculated mean value of each three data points was used for the analyses. A principal component (PC) analysis (PCA) was performed with the software Stata v.11 (StataCorp, College Station, TX, USA). The first two PCs were plotted to examine whether any group of specimens could be distinguished. Then the groups that were found in the PCA plot were compared to the morphospecies or genetic groups inferred from the molecular analyses. Comparisons between morphospecies and morphometric data were also performed by a one-way analysis of variance (ANOVA) for parametric data or a Kruskal-Wallis one-way ANOVA for nonparametric data, and all pairwise multiple comparisons were performed with Tukey's test (parametric) or Dunn's test (nonparametric) using SigmaStat 3.0.1 (SPSS, Chicago, IL, USA).

\section{Results}

\section{Species identification}

In total, 74 samples (excluding two colonies of G. columna as outgroups) were collected from 14 locations in Japan, and seven morphospecies, including G. stokesi (13 colonies), G. sp. cf. stokesi (1), G. lobata (8), G. sp. cf. lobata (4), G. djiboutiensis (16), G. sp. cf. djiboutiensis (26), and G. pendulus (6), were identified (Figures 3 and 4; hereafter 'sp.' is not shown when referring to the morphospecies). Species lists and locations are summarized in Table 1. Several specimens had morphological characters atypical of the species. It is likely that some represented intraspecific morphological variations, but it was difficult to determine whether they were intraspecific morphological variations or different species. Therefore, we added 'confer (cf.)' followed by the species name where specimens were similar to a species but differed in more than one character from a species (Table 1). The morphospecies with the largest number of collected samples (26 colonies) was G. cf. djiboutiensis. G. pendulus is similar to G. lobata and G. djiboutiensis in skeletal morphology but differs in its irregular polygonal calices and reduced septa. The morphologies of G. stokesi clearly differed from those of the other morphospecies (see below discussion for details).

\section{G. stokesi and morphologically similar colonies}

Thirteen colonies of G. stokesi with a typical colony shape (i.e., free-living with large polyps) (Figure 3) were collected from three sites (IR, NK, and OU) in Okinawa; such colonies were not found at TN (Figure 1). The G. stokesi collected in this study had elongated polyps $(>5 \mathrm{~cm})$ with long tapering tentacles (about $1 \mathrm{~cm}$ ). The polyps were pale brown which gradually turned white toward the 

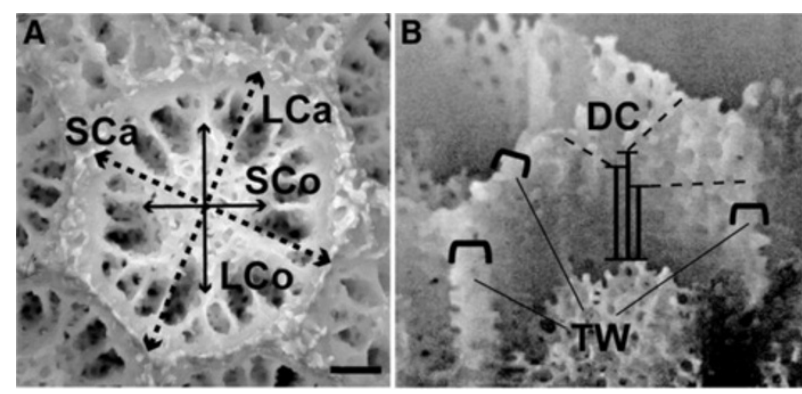

Figure 2 Measurements of morphological characters of Goniopora. (A) Corallite characters: long diameter of calice (LCa), short diameter of calice (SCa), long diameter of columella (LCO), and short diameter of columella (SCO). (B) Vertical section of corallites: depth of walls (DW) and thickness of walls (TW). Bar $=1 \mathrm{~mm}$.

tip of the tentacles and had white oral discs. They were found only on mud in waters deeper than $18 \mathrm{~m}$, even where there were several rocky patches available at the same depth.

Table 2 summarizes field observations of G. stokesi at Okinawa. At OU, more than one half of the colonies observed in the field (approximately 20 colonies) had daughter colonies (connected to parental colonies by tissue) approximately $1 \mathrm{~cm}$ in diameter on the colony surface (Figure 3B,D). We also observed several small colonies $(<2 \mathrm{~cm}$ in diameter) around larger colonies $(3$ to $10 \mathrm{~cm}$ in diameter). Furthermore, all of these colonies were free-living and found on mud, although four of the thirteen colonies that we collected were attached to a small piece of dead coral skeleton. Tissues around the bottom of the colonies were typically swollen.

In the temperate region, we found only three colonies (AM74, AM75, and AM89) with free-living forms at AM (Figure 5A1,A2 and Table 2), where the existence of $G$. stokesi had previously been reported (Nishihira and Veron 1995). We did not find these forms at any other study site in the temperate region. Their skeletal morphologies, however, indicated that they were not G. stokesi, but rather G. djiboutiensis or G. cf. djiboutiensis (Figures 4 and 5), because these three colonies had smaller corallites $(<5 \mathrm{~mm})$ and thicker walls than those of G. stokesi
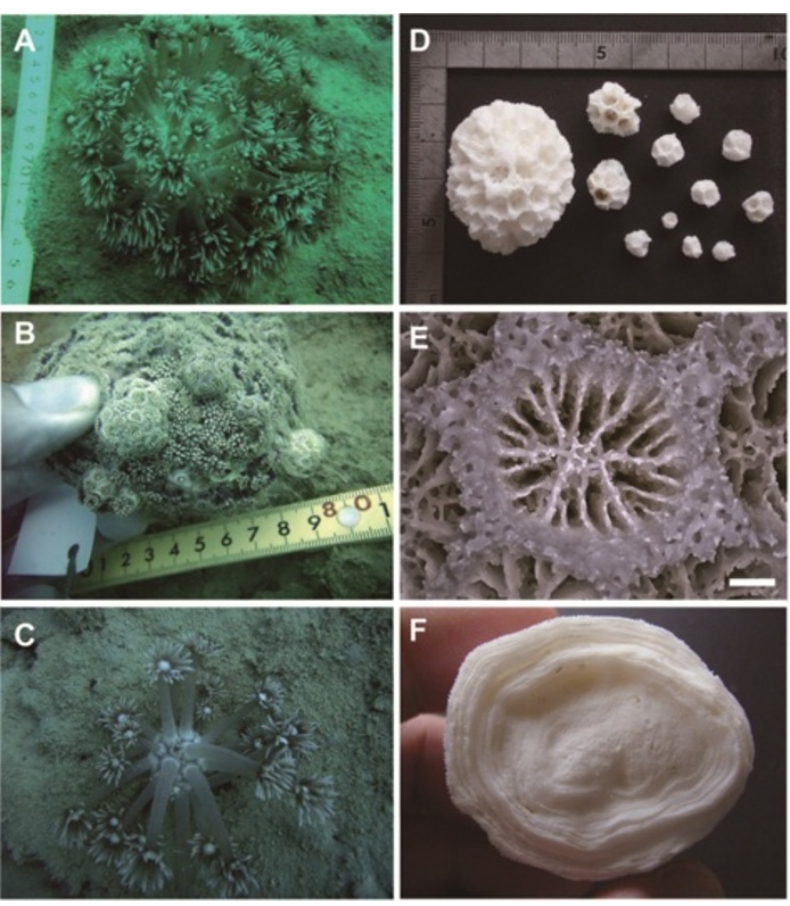

Figure 3 Goniopora stokesi at Oura Bay. (A) Living specimen with elongated polyps. (B) Living specimens with shrunken polyps and several daughter colonies attached. (C) Living daughter colony with elongated polyps. (D) Skeletons of parent and daughter colonies. (E) Corallites of parent colony. (F) An epitheca on the underside with concentric circles. Bar $=2 \mathrm{~mm}$. 

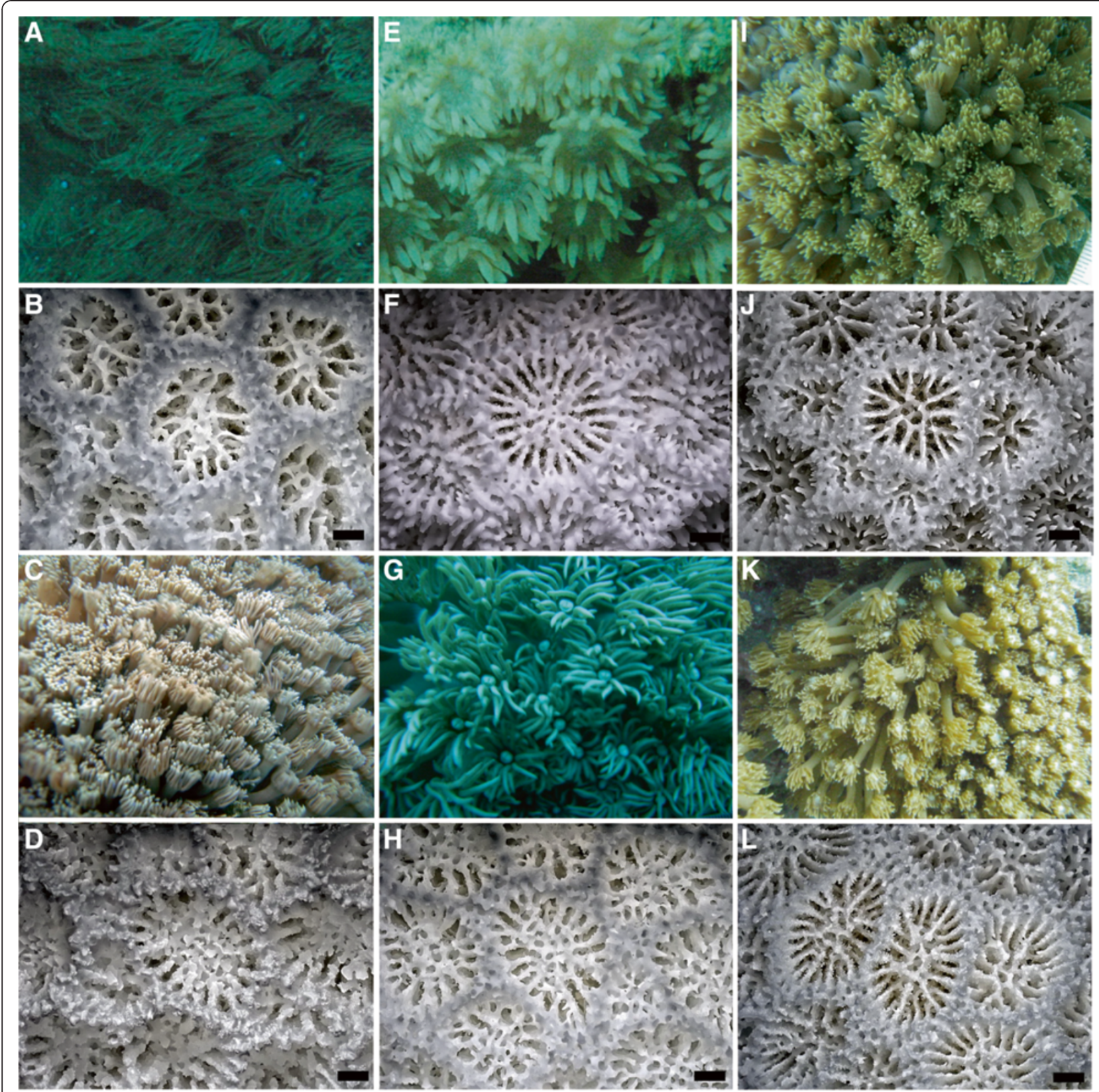

Figure 4 Goniopora spp. examined in this study. Polyps (A) and corallites (B) of G. pendulus (OT31), G. cf. stokesi (MO82) (C, D), G. djiboutiensis (OT30) (E, F), G. cf. djiboutiensis (KK11) (G, H), G. lobata (KS28) (I, J), and G. cf. lobata (SR14) (K, L). Each bar = 1 mm.

(see below discussion and Tables 3 and 4 for results of the morphological analyses). In addition, there was no well-developed epitheca on the underside of each corallum (Figure 5A2).

However, at IR and MO we found three G. stokesi-like specimens that were completely attached to hard substrates. Polyps of two of these three colonies looked very similar to those of G. stokesi in the water (Figure 5B1, C1) upon comparison with polyps of G. stokesi at OU and photographs of living specimens in the literature
(Veron 2000), but their skeletal features were not similar to those of G. stokesi. Based on skeletal characters, they were identified as either G. djiboutiensis or G. cf. djiboutiensis (Figure 5A3, C2). Another colony had skeletal characters similar to those of G. stokesi, excluding the width of the columella (Figure 4D, Tables 3 and 4); although the morphology of the polyps (evenly extended with terete tentacles of even length; Figure 4C; Veron (2000)) was similar to that of Goniopora tenuidens. We treated this colony as G. cf. stokesi. 
Table 2 Summary of ecological and morphological features of Goniopora stokesi and G. stokesi-like specimens

\begin{tabular}{|c|c|c|c|c|c|c|c|}
\hline \multirow[b]{2}{*}{ Site $^{a}$} & \multicolumn{3}{|c|}{ G. stokesi } & \multicolumn{4}{|c|}{ G. stokesi-like specimens } \\
\hline & $\overline{\mathrm{OU}}$ & NK & IR & $\overline{A M}$ & IR & MO & MO \\
\hline $\begin{array}{l}\text { No. of colonies } \\
\text { collected }\end{array}$ & $\begin{array}{l}\text { OU12, OU14, OU17, OU19, } \\
\text { OU20, OU22, OU24, OU26, } \\
\text { OU41, OU43 }\end{array}$ & NK1 & IR27, IR65 & $\begin{array}{l}\text { AM74 } \\
\text { AM75 } \\
\text { AM89 }\end{array}$ & IR22 & MO53 & MO82 \\
\hline Sampling date & May and October 2009 & August 2010 & $\begin{array}{l}\text { June and } \\
\text { August } 2011\end{array}$ & December 2011 & June 2011 & March 2011 & February 2011 \\
\hline $\begin{array}{l}\text { No. of colonies } \\
\text { observed in the field }\end{array}$ & $>20$ & $>20$ & 2 & 3 & 1 & 1 & 1 \\
\hline Living form & Free-living & Free-living & Free-living & Free-living & Attached & Attached & Attached \\
\hline Depth (m) & 18 to 29 & 20 & 21 to 29 & 3 to 10 & 19 & 10 & 6 \\
\hline Daughter colonies & Yes & Yes & No & No & No & No & No \\
\hline Polyp morphology & G. stokesi & G. stokesi & G. stokesi & G. djiboutiensis & G. stokesi & G. stokesi & G. tenuidens \\
\hline Skeletal morphology & G. stokesi & G. stokesi & G. stokesi & $\begin{array}{l}\text { G. djiboutiensis or } \\
\text { G. cf. djiboutiensis }\end{array}$ & G. djiboutiensis & G. cf. djiboutiensis & G. cf. stokesi \\
\hline
\end{tabular}

${ }^{a}$ Site abbreviations are defined in Figure 1. See Table 1 for more information.

\section{Molecular analyses}

The molecular-based phylogenetic tree based on ND5COI (Figure 6) classified the species analyzed in this study into two main clades (clades I and II). Clade I included specimens from temperate regions identified as G. cf. stokesi (1 colony), G. pendulus (3), G. cf. djiboutiensis
(3), and G. cf. lobata (1). In the same clade, specimens from subtropical regions identified as G. stokesi (9), G. pendulus (1), and G. cf. djiboutiensis (3) were retrieved. In clade II, specimens from temperate regions included those identified as G. lobata (3), G. cf. lobata (1), G. djiboutiensis (2), and G. cf. djiboutiensis (4), and those from
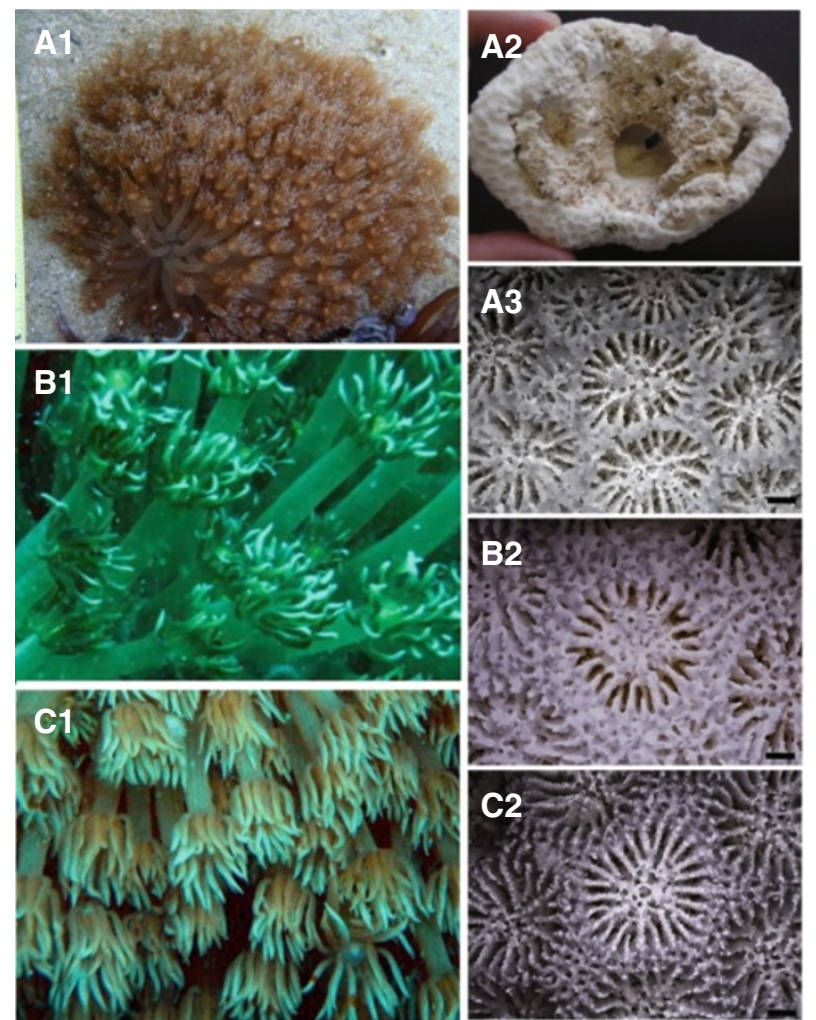

Figure 5 Goniopora spp. with living morphologies that are similar to that of G. stokesi. Living specimen (A1), underside of the corallum (A2), and corallite structures (A3) of a free-living form of G. djiboutiensis (AM74) at AM. Living specimen (B1) and corallite structures (B2) of G. djiboutiensis (IR22). Living specimen (C1) and corallite structures (C2) of $\mathrm{G}$. of. djiboutiensis (MO53). Polyps of colonies IR22 and MO53 are similar to those of $\mathrm{G}$. stokesi. Each bar $=2 \mathrm{~mm}$. 
Table 3 Morphological variables of Goniopora used in the analysis (mean \pm SD)

\begin{tabular}{|c|c|c|c|c|c|c|c|c|c|c|c|c|}
\hline \multirow[b]{2}{*}{ ITS clade type } & \multicolumn{9}{|c|}{ Description/value } & \multicolumn{3}{|c|}{ Between ITS clades } \\
\hline & la & $\mathrm{Ib}$ & $\mathrm{Ib}$ & $\mathrm{Ib}$ & $\mathrm{lb}$ & $\|$ & $\|$ & $\|$ & $\|$ & la & $\mathrm{Ib}$ & $\|$ \\
\hline No. of colonies & 5 & 1 & 4 & 4 & 1 & 5 & 6 & 4 & 3 & 5 & 10 & 18 \\
\hline Morphospecies & G. stokesi & G. cf stokesi & G. pendullus & G. of djiboutiensis & G. cf lobata & G. djiboutiensis & G. cf djiboutiensis & G. lobata & G. cf lobata & & & \\
\hline \multicolumn{13}{|l|}{ Measured variable } \\
\hline $\mathrm{LCa}(\mu \mathrm{m})$ & $5313 \pm 840.8$ & $4781 \pm 437.6$ & $4313 \pm 438.5$ & $4726 \pm 461.7$ & $3925 \pm 144.2$ & $4721 \pm 630.1$ & $4730 \pm 483.1$ & $4268 \pm 440.2$ & $3847 \pm 282.6$ & $5313 \pm 840.8$ & $4486 \pm 501.4$ & $4477 \pm 593.4$ \\
\hline LCo $(\mu \mathrm{m})$ & $2853 \pm 663.3$ & $3279 \pm 448.9$ & $2477 \pm 405.5$ & $2804 \pm 470.7$ & $2388 \pm 224.5$ & $3081 \pm 566.8$ & $2975 \pm 527.7$ & $2349 \pm 470.9$ & $2370 \pm 218.7$ & $2853 \pm 663.3$ & $2678 \pm 488.5$ & $2764 \pm 583.3$ \\
\hline $\mathrm{DC}(\mathrm{mm})$ & $3.40 \pm 0.91$ & $3.47 \pm 0.36$ & $2.32 \pm 0.98$ & $2.09 \pm 0.67$ & $2.68 \pm 0.69$ & $1.21 \pm 0.51$ & $2.10 \pm 0.72$ & $2.22 \pm 0.56$ & $1.34 \pm 0.15$ & $3.40 \pm 0.91$ & $2.38 \pm 0.87$ & $1.76 \pm 0.72$ \\
\hline TW (mm) & $0.89 \pm 0.15$ & $0.91 \pm 0.07$ & $1.30 \pm 0.28$ & $1.23 \pm 0.22$ & $1.14 \pm 0.27$ & $1.34 \pm 0.35$ & $1.30 \pm 0.28$ & $1.22 \pm 0.23$ & $1.27 \pm 0.29$ & $0.89 \pm 0.15$ & $1.22 \pm 0.26$ & $1.29 \pm 0.29$ \\
\hline \multicolumn{13}{|l|}{ Counted variable } \\
\hline No. of septa & $22.6 \pm 1.55$ & $21.4 \pm 1.67$ & $19.5 \pm 1.67$ & $23.3 \pm 2.47$ & $23.2 \pm 1.10$ & $23.9 \pm 0.67$ & $23.3 \pm 1.95$ & $22.9 \pm 1.68$ & $23.9 \pm 1.36$ & $22.6 \pm 1.55$ & $21.6 \pm 2.67$ & $23.5 \pm 1.55$ \\
\hline \multicolumn{13}{|l|}{ Derived variable } \\
\hline $\mathrm{LCo} / \mathrm{LCa}^{\mathrm{a}}$ & $0.54 \pm 0.08$ & $0.69 \pm 0.08$ & $0.57 \pm 0.08$ & $0.59 \pm 0.08$ & $0.61 \pm 0.05$ & $0.65 \pm 0.06$ & $0.63 \pm 0.09$ & $0.55 \pm 0.09$ & $0.62 \pm 0.06$ & $0.54 \pm 0.08$ & $0.60 \pm 0.08$ & $0.62 \pm 0.09$ \\
\hline SCa/LCa & $0.87 \pm 0.07$ & $0.73 \pm 0.09$ & $0.84 \pm 0.09$ & $0.81 \pm 0.08$ & $0.79 \pm 0.22$ & $0.87 \pm 0.05$ & $0.86 \pm 0.08$ & $0.80 \pm 0.08$ & $0.82 \pm 0.09$ & $0.87 \pm 0.07$ & $0.81 \pm 0.11$ & $0.84 \pm 0.08$ \\
\hline $\mathrm{SCO} / \mathrm{LCo}^{\mathrm{a}}$ & $0.81 \pm 0.11$ & $0.70 \pm 0.15$ & $0.57 \pm 0.13$ & $0.71 \pm 0.12$ & $0.78 \pm 0.09$ & $0.80 \pm 0.08$ & $0.84 \pm 0.11$ & $0.72 \pm 0.12$ & $0.79 \pm 0.14$ & $0.81 \pm 0.11$ & $0.70 \pm 0.14$ & $0.79 \pm 0.12$ \\
\hline
\end{tabular}

${ }^{2}$ The parametric analysis (see 'Methods'). LCa, long diameter of calice; LCo, long diameter of columellae; DC, depth of calices; TW, thickness of walls; LCo/LCa, ratio of LCo and LCa; SCa/LCa, ratio of SCa and LCa; SCo/LCo, ratio of SCo and LCo. 


\section{Table 4 Multiple pairwise comparisons of morphological variables of Goniopora}

\begin{tabular}{|c|c|c|c|c|c|c|c|c|c|c|c|c|}
\hline \multirow[b]{2}{*}{ ITS clade type } & \multicolumn{9}{|c|}{ Description/value } & \multicolumn{3}{|c|}{ Between ITS clades } \\
\hline & la & $\mathrm{Ib}$ & $\mathrm{Ib}$ & $\mathrm{lb}$ & $\mathrm{Ib}$ & $\|$ & $\|$ & $\|$ & $\|$ & la & $\mathrm{Ib}$ & $\|$ \\
\hline Serial number & 1 & 2 & 3 & 4 & 5 & 6 & 7 & 8 & 9 & & & \\
\hline Morphospecies & G. stokesi & G. cf stokesi & G. pendullus & G. cf djiboutiensis & G. cf lobata & G. djiboutiensis & G. cf djiboutiensis & G. lobata & G. cf lobata & & & \\
\hline \multicolumn{13}{|c|}{ Measured variable } \\
\hline $\mathrm{LCa}(\mu \mathrm{m})$ & $3,5,8,9$ & 9 & 1 & 9 & 1 & 9 & 9 & 1 & $1,2,4,6,7$ & $|b| \mid$, & la & la \\
\hline LCo $(\mu \mathrm{m})$ & & 9 & & & & 9 & 9 & & $2,6,7$ & $\mathrm{Ib}$ & $|\mathrm{a}| \mid$, & $\mathrm{Ib}$ \\
\hline $\mathrm{DC}(\mathrm{mm})$ & 6 & 6,9 & 6 & 6 & 6 & 1 to $5,7,8$ & 6 & 6 & 2 & $|b| \mid$, & $|\mathrm{a}| \mid$, & $\mathrm{la}, \mathrm{IB}$ \\
\hline TW (mm) & & & & & & & & & & $|b| \mid$, & la & la \\
\hline \multicolumn{13}{|l|}{ Counted variable } \\
\hline No. of septa & & & $6,7,9$ & & & 3 & 3 & & 3 & $\|$ & $\|$ & $\mathrm{la}, \mathrm{lb}$ \\
\hline \multicolumn{13}{|c|}{ Derived variable } \\
\hline $\mathrm{LCO} / \mathrm{LCa}^{\mathrm{a}}$ & $2,6,7,9$ & 1,8 & & & & 1,8 & 1,8 & $2,6,7$ & 1 & $|b| \mid$, & la & la \\
\hline \multicolumn{13}{|l|}{$\mathrm{SCa} / \mathrm{LCa}$} \\
\hline $\mathrm{SCO} / \mathrm{LCo}^{\mathrm{a}}$ & 2 & $1,6,7,9$ & 7 & 7 & & 2 & $2,3,4,8$ & 7 & 2 & $\mathrm{lb}$ & $|a| \mid$, & $\mathrm{lb}$ \\
\hline
\end{tabular}

${ }^{\mathrm{a}}$ The parametric analysis (see 'Methods'). Serial numbers are only shown for pairwise comparisons that significantly differed $(p<0.05)$. LCa, long diameter of calice; LCo, long diameter of columellae; DC, depth of calices; TW, thickness of walls; LCo/LCa, ratio of LCo and LCa; SCa/LCa, ratio of SCa and LCa; SCo/LCo, ratio of SCo and LCo. 


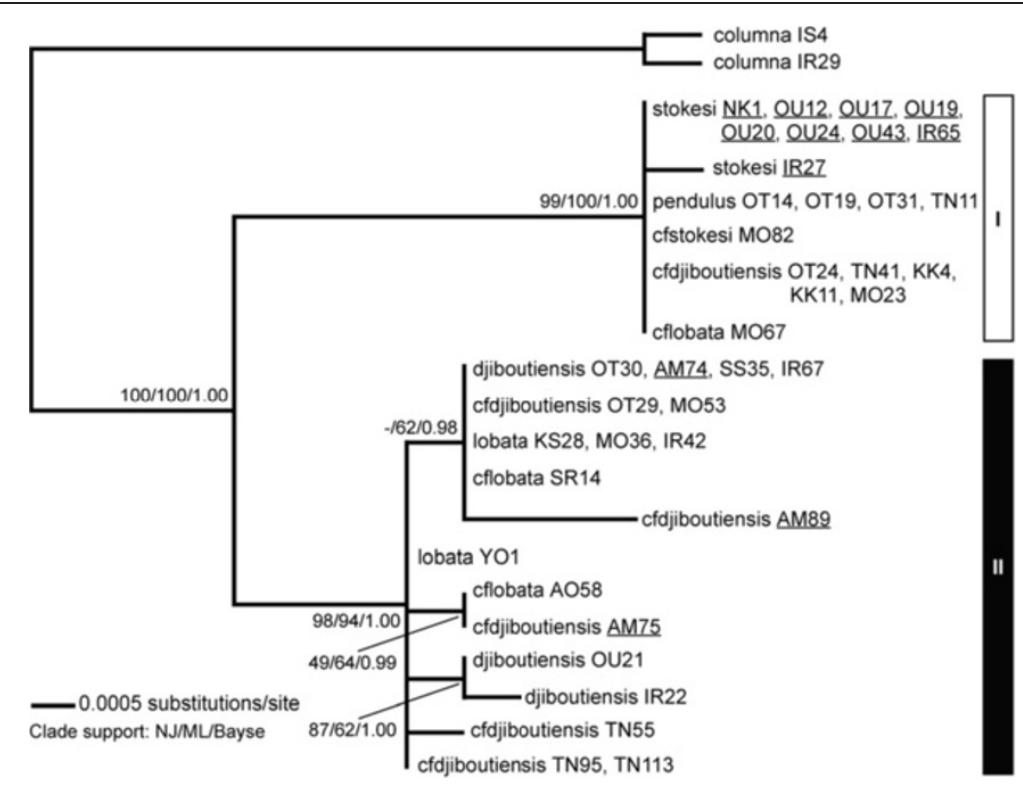

Figure 6 Maximum-likelihood (ML) phylogenetic tree of the NADH dehydrogenase subunit 5 (ND5)-cytochrome oxidase subunit 1 (COI) dataset. See Table 1 for species names and colony numbers. Bootstrap values (\%) for the neighbor-joining (NJ) and ML analyses, and probability values for the Bayesian inferences (BIs), are shown on the branches. Underlining of a sample number indicates a free-living form.

subtropical regions included G. lobata (1), G. cf. lobata (2), G. djiboutiensis (4), and G. cf. djiboutiensis (3). Thus, in the ND5-COI tree, G. stokesi was indistinguishable from the other species.

In the ITS tree (Figure 7), G. stokesi (clade Ia), which partially corresponded to clade I of the ND5-COI tree, was genetically separate from the other clades (Ib, II). Species groups (G. lobata, G. cf. lobata, G. djiboutiensis, and G. cf. djiboutiensis), which corresponded to clade II of the ND5-COI tree, also formed a single clade (clade II in the ITS tree). Although clade II in the ITS tree appeared to be divided into two subclades (Figure 7), the division of these subclades was not related to differences in morphospecies, i.e., alleles from a single colony were separately included in both subclades.

\section{Morphological analyses}

Seven morphometric variables (LCa, SCa, LCo, SCo, the number of septa, CD, and TW) were scored from 33 specimens (165 corallites). A PCA biplot of the morphometric data for these specimens is shown in Figure 8. The first two PCs accounted for $66.2 \%$ of the total variance. PC1 was positively correlated with all parameters, especially LCo, SCo, LCa, and SCa $(r>0.8)$. No groups were clearly visible in the PCA plot, but at least two groups were likely separable when we applied these plots to the clades in the ITS tree (Figure 8A) and morphospecies (Figure 8B). G. stokesi and G. djiboutiensis (or clade II) were particularly likely to belong to different groups, although G. pendulus (or clade Ib) overlapped between them.

In the specimens we observed, the epitheca had only developed on the underside of G. stokesi; however, we were unable to determine the presence of the epitheca in one large colony of G. stokesi because we did not collect part of the underside and did not check for its presence in the field.

Then, we performed multiple comparisons of each variable or character. Development of pali and septal arrangements were too variable even within a single morphospecies, and their comparisons showed no significant differences among morphospecies (data not shown). Values of short diameter of either columella or calice (SCo or SCa) were directly proportional to their long diameter (LCo or LCa) (data not shown); therefore, we only used LCo and LCa in this study. The dataset for a total of eight variables is shown in Tables 3 and 4. Pairwise multiple comparisons showed that G. stokesi was significantly separable from G. pendulus (clade Ib), G. cf. lobata (Ib), G. lobata (II), and G. cf. lobata for LCa ( $p<0.05$, Dunn's test), from G. cf. djiboutiensis (II) for DC ( $p<0.05$, Dunn's test), from G. cf. stokesi (Ib), G. djiboutiensis (II), G. cf. djiboutiensis (II), and G. lobata (II) for LCo/LCa ( $p<0.05$, Tukey's test), and from G. cf. stokesi for SCo/LCo $(p<0.05$, Tukey's test). For other species, G. djiboutiensis (II) was significantly ( $p<0.05$, Dunn's test) separable from all others, including $G$. cf. djiboutiensis, for DC. However, other variables did not show sufficient differences to separate them from one another. In 


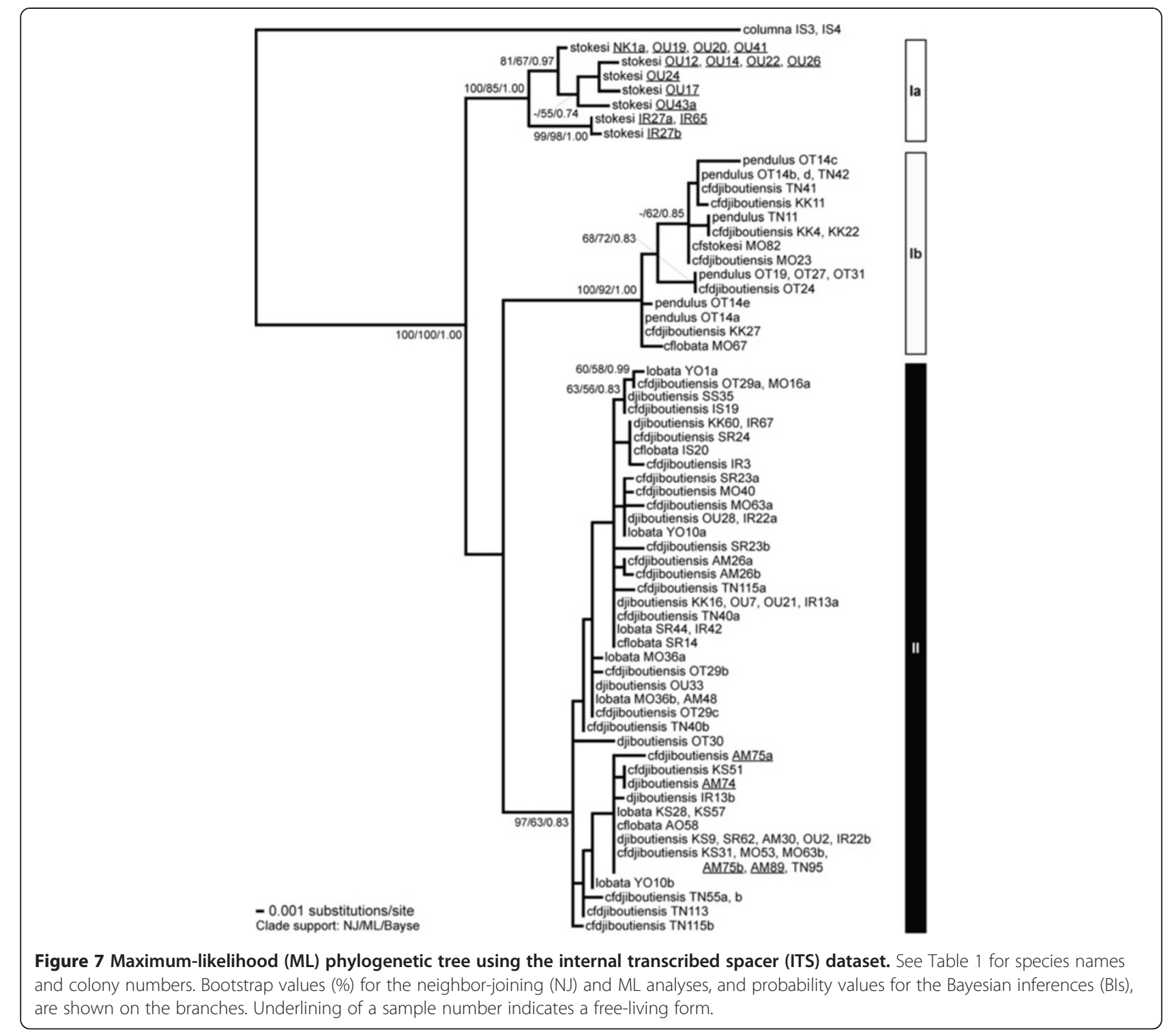

summary, combinations of several morphological variables could at least separate G. stokesi from the others, whereas other morphological variables that were able to separate other morphospecies could not be identified except for DC for G. djiboutiensis.

\section{Discussion}

Phylogeny and taxonomy of G. pendulus, G. djiboutiensis, and G. lobata

There were no significant differences in the morphological variables of corallites (SCo, LCo, SCa, LCa, DC, TW, and number of septa) between G. pendulus and G. lobata, even though the original description (Veron 1985) of G. pendulus stated that corallites and columellae of G. pendulus were larger than those of G. lobata. Nevertheless, G. pendulus could be separated from $G$. lobata based on a reduced septal number and the length of the polyps and tentacles (much longer in G. pendulus than in G. lobata; Veron (1985)). Although each of these two characters varied within and between species (e.g., long tentacles were observed in some colonies of G. cf. djiboutiensis), their combination could largely separate these species.

We could not clearly distinguish among the four morphospecies (G. djiboutiensis, G. cf. djiboutiensis, G. lobata, and G. cf. lobata) based on either morphological or phylogenetic analyses. In particular, G. cf. djiboutiensis and G. cf. lobata were included in both clades Ib and II in the ITS tree (Figure 7). Considering that these clades were clearly separate, it is highly possible that G. cf. djiboutiensis and G. cf. lobata in the two clades (Ib and II) represent different species. Because G. pendulus, the only one that did not appear in other clades, was the main species in clade 

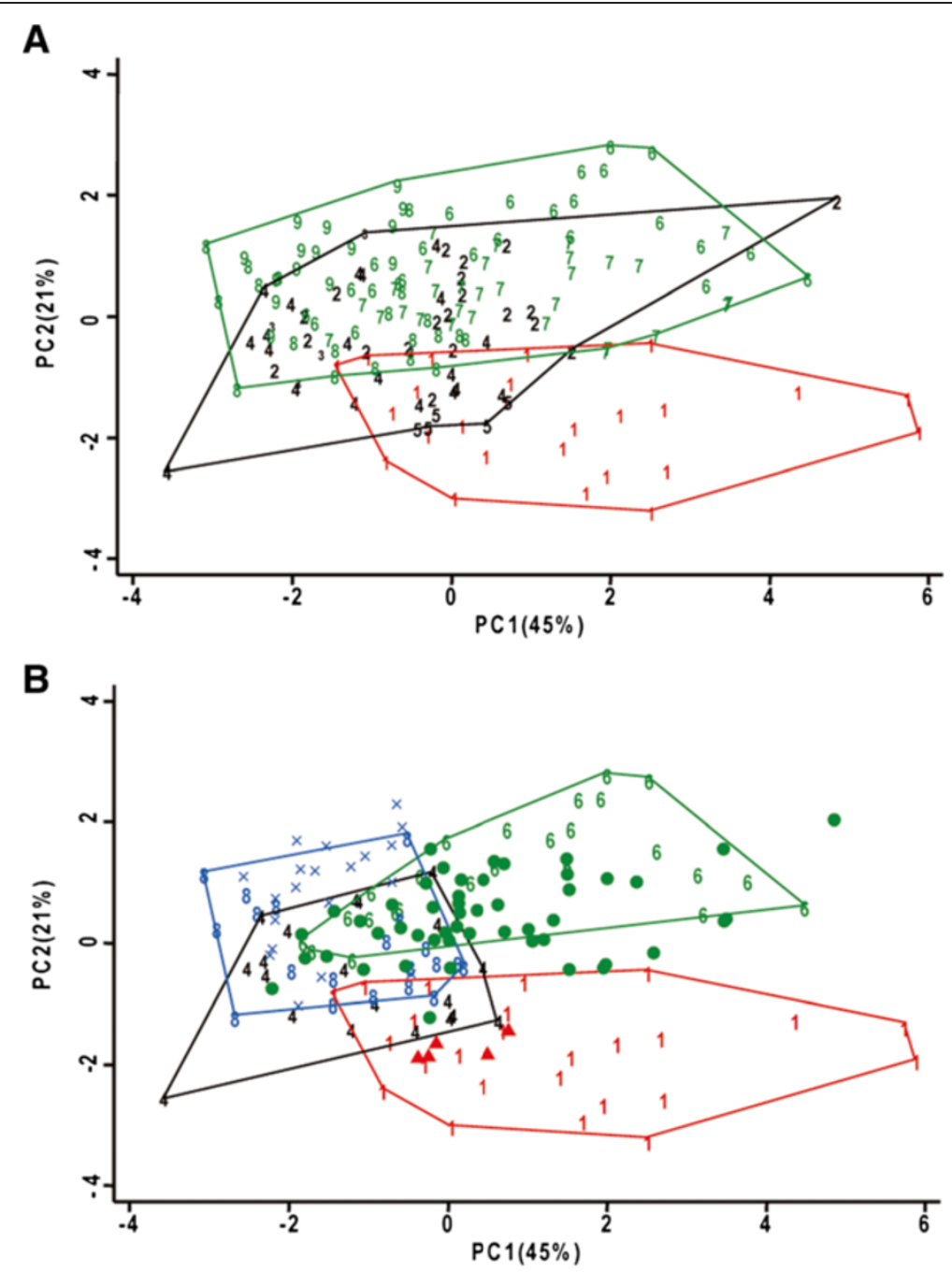

Figure 8 Results from a principal component analysis of morphometric data from Goniopora spp. Grouping by clades in the internal transcribed spacer (ITS) tree (A) and grouping by morphospecies (B). In A, the group in red represents clade I, the group in black represents clade Ib, and the group in green represents clade II. Numbers are defined as follows; 1, G. stokesi; 2, G. cf. djiboutiensis (clade Ib); 3, G. cf. lobata (Ib); 4, G. pendulus; 5, G. cf. stokesi; 6, G. djiboutiensis; 7, G. cf. djiboutiensis (II); 8, G. lobata; and 9, G. cf. lobata (II). In B, the group in red represents G. stokesi, the group in black represent G. pendulus, the group in green represents $G$. djiboutiensis, and the group in blue represents $G$. lobata. Symbols are defined as follows: red triangles, G. cf. stokesi; green circles, G. cf. djiboutiensis; and blue crosses, G. cf. lobata.

Ib, the two morphs, G. cf. djiboutiensis and G. cf. lobata, in clade Ib (not in clade II) might represent morphological variations of G. pendulus. For morphospecies in clade II, G. djiboutiensis had very shallow corallites, which could be a good character to separate it from the others (Tables 3 and 4). In general, it was quite difficult to identify these Goniopora species based on macro-morphologies that have typically been used in the taxonomy of this group. In the future, a more-detailed morphological analysis of microstructures using scanning electron microscopy is necessary (if they are separate species), as has been done with other families of scleractinian corals (Benzoni et al. 2007; Budd and Stolarski 2011). Crossing experiments may also be useful in detecting species boundaries.

\section{Reproductive mechanism of G. stokesi}

It was reported that G. stokesi releases daughter colonies asexually in the Maldives, Nicobar Islands, Seychelles, and Australia (Scheer 1960; Rosen and Taylor 1969; Veron and Pichon 1982). However, this type of asexual reproduction has never been observed in Japan (Nishihira and Veron 1995). This is the first report of the formation of daughter colonies by G. stokesi in Japan. We also found that this species inhabits only muddy habitats at water depths of $>18 \mathrm{~m}$ in Okinawa, Japan, whereas in the Seychelles, it inhabits protected sandy areas such as lagoons at $1 \mathrm{~m}$ in depth (Rosen and Taylor 1969). As noted by Rosen and Taylor (1969), this unique reproductive mechanism of releasing daughter colonies is associated with colonization 
of unstable soft substrates. Indeed, we observed daughter colonies only on top of the mud. They had swollen tissues, which prevented them from becoming buried. It is possible that such daughter colonies could be affected by strong currents associated with rocky environments, thus limiting their distribution to more-protected environments, such as deeper areas or inside lagoons. Additionally, in OU, many daughter colonies were found on and around parent colonies in spring (May) and autumn (October), suggesting that this asexual reproduction may frequently occur throughout the year. It is clear that the formation of asexual daughter colonies is an important reproductive mechanism in this species, while sexual reproduction has never been observed.

Regarding the molecular phylogeny based on the ITS, all samples of G. stokesi formed a single clade and were clearly separated from morphologically closely related species, including G. djiboutiensis, G. lobata, and G. pendulus (Figure 7). This result strongly supports the idea that G. stokesi is a genetically isolated species from G. stokesilike colonies (see below).

\section{G. stokesi-like colonies and free-living forms}

We found that colonies attached to hard substrates and with a similar morphology (tentacles or skeletons) to G. stokesi did not actually belong to this species (Table 2). Several previous studies reported that G. stokesi unusually attaches to hard substrates (Nemenzo 1955; Veron and Pichon 1982; Veron 2000). However, our data suggest that (at least in Japan) colonies that attach to hard substrates are not G. stokesi. Further analyses of such colonies from locations outside Japan are necessary to clarify whether G. stokesi attaches to hard substrates, such as other corals.

We also found three free-living colonies in AM in the temperate region. In general, any free-living forms of Goniopora were presumably G. stokesi. However, their morphology differed from that of typical G. stokesi. The underside of the coralla was slightly hollow (Figure 5A2) or may have been broken and lacked an epitheca (Figure 3F). In addition, other colonies with the same skeletal characters as these three colonies, which were identified as G. djiboutiensis or G. cf. djiboutiensis, were found attached to rocks near sand. This suggests that they are intraspecific morphological variations of $G$. djiboutiensis and that these free-living colonies were not adapted to living on sand but had accidentally grown there, probably after breaking off a rock.

There are two types of free-living corals. One type consists of corals that are permanently free-living, such as fungiids, while the other type consists of those that are secondarily and accidentally free-living (Pichon 1974). Secondarily and accidentally free-living forms were observed in some species from other genera (Acropora, Riegl et al. (1996); Pavona and Porites, Glynn (1974), Scoffin et al.
(1985); and Siderastrea, Lewis (1989)), which are possibly an adaptation to a disturbed habitat (Lewis 1989). They are known to have spheroidal growths like rolling stones, which are called coralliths (Glynn 1974). It was reported that the formation of coralliths needs periodic movement by waves and currents or disturbance by browsing fish (Murray 1885; Glynn 1974). However, coralliths differ from what was observed in the present study. Free-living forms in AM did not become coralliths because the underside of these corals was completely dead (no living tissue). Species of the genus Goniopora share common morphological characteristics, such as long tentacles and thick tissues, which can prevent them from being buried in sand. Because of these characteristics, they can survive on sand without becoming corallith forms.

\section{Conclusions}

Our investigation revealed that G. stokesi is free-living, forms daughter colonies, and in Okinawa, Japan, was found on the mud below $18 \mathrm{~m}$ of water. This is the first report of asexual reproduction by G. stokesi in Japan. Molecular phylogenetic analyses using ITSs (but not mitochondrial markers) revealed that $G$. stokesi was genetically isolated from other morphologically related species. We identified several other colonies that looked like G. stokesi, but in fact belonged to other species. Overall, G. stokesi is distinguishable from morphologically related species by a combination of the following characters: being free-living; living on soft substrates in protected environments; and having large, deep calices, thin walls, and a well-developed epitheca on the underside of the corallum. However, because the morphological features of Goniopora species can overlap, it is important to also use genetic techniques to confirm species boundaries. Currently, molecular phylogenetic analyses using ITS markers (in comparison with ND5-COI) are the most useful means of separating these morphospecies and recognizing morphological variations in each genetic group, although it is necessary to look for additional markers to distinguish morphospecies within clades. Based on our results, novel morphological characteristics, including detailed polyp morphologies or microstructures, may be identified in the future. Because Goniopora species are sometimes abundant even on the coast of Japan, it is important to further elucidate their detailed taxonomy to estimate species diversity and/or regional specificity.

\section{Competing interests}

The authors declare that they have no competing interests.

\section{Authors' contributions}

YFK carried out the molecular phylogenetic and morphological studies, collected samples, and drafted the manuscript. MO and DU participated in the design of the study and collected samples. KM participated in the design and coordination of the study. HF conceived of the study, collected samples, and participated in its design and coordination. All authors read and approved the final manuscript. 


\section{Acknowledgements}

We thank F Iwase, T Mezaki (Biological Institute on Kuroshio, Kochi, Japan), and K Nomura (Kushimoto Marine Park, Wakayama, Japan) for assistance with field research, and G Suzuki (Ishigaki Tropical Station, Seikai National Fisheries, Okinawa, Japan), JD Reimer, T Fujii, K Sakai, and T Naruse (University of the Ryukyus in Okinawa, Japan) for their assistance with field research and for sample collection with permission from the Okinawa Prefectural Government. We would also like to thank the staff of the Seto Marine Biological Laboratory at Kyoto University and the members of the Japanese Society for Coral Taxonomy. Some of the samples were collected in a field research project funded by the NEXT program (GR083, Japan Society for the Promotion of Science) conducted by T Sakamaki (University of the Ryukyus). Financial support was provided by grants from the Japan Society for the Promotion of Science, Grants-in-Aid for Scientific Research (B) to HF (22370033). The Sasagawa Scientific Foundation also provided financial support to YFK (23-515).

\section{Author details}

${ }^{1}$ Seto Marine Biological Laboratory, Field Science and Education Center, Kyoto University, 459 Shirahama, Wakayama 649-2211, Japan. ${ }^{2}$ Biological Institute on Kuroshio, 560 Nishidomari, Otsuki 788-0333Kochi, Japan. ${ }^{3}$ Faculty of Science, University of the Ryukyus, 1 Senbaru, Nishihara 903-02130kinawa, Japan. ${ }^{4}$ Department of Marine Biology and Environmental Science, Faculty of Agriculture, University of Miyazaki, 1-1 Gakuen-kibanadai Nishi, Miyazaki 889-2192, Japan.

Received: 16 September 2012 Accepted: 12 April 2013 Published: 1 October 2013

\section{References}

Bedot M (1907) Madréporaires d'Amboine. Rev Suisse Zool 15:143-292, pl. 5-50

Benzoni F, Stefani F, Stolarski J, Pichon M, Mitta G, Galli P (2007) Debating phylogenetic relationships of the scleractinian Psammocora: molecular and morphological evidences. Contrib Zool 76:35-54

Benzoni F, Stefani F, Pichon M, Galli P (2010) The name game: morpho-molecular species boundaries in the genus Psammocora (Cnidaria, Scleractinina). Zool J Linn Soc 160:421-456

Bernard HN (1903) The family Poritidae, I: The genus Goniopora. Cat Madreporarian Corals Br Mus (Nat Hist) 4:1-206, pl. 1-14

Budd AF, Stolarski J (2011) Corallite wall and septal microstructure in scleractinian reef corals: comparison of molecular clades within the family Faviidae. J Morphol 272:66-88

Crossland C (1952) Madreporaria, Hydrocorallinae, Helliopora and Tubipora. Great Barrier Reef Expedition 1928-29. Sci Rep Br Mus (Nat Hist) 6:85-257, pl 1-56

Dana JD (1846) Zoophytes. In: United States exploring expedition during the years 1838, 1839, 1840, 1841, 1842 under the command of Charles Wilkes. U. S.N. Lea and Blanchard, 7, Philadelphia, PA, p 740

Faustino LA (1927) Recent Madreporaria of the Philippine islands. Ber Sci Manila Monogr 22:1-310, pl. 1-100

Forsman ZH, Barshis DJ, Hunter CL, Toonen RJ (2009) Shape-shifting coral: molecular markers show morphology is evolutionarily plastic in Porites. BMC Evol Biol 9:45. doi:10.1186/1471-2148-9-45

Fukami H, Budd AF, Levitan DR, Jara J, Kersanach R, Knowlton N (2004) Geographic differences in species boundaries among members of the Montastraea annularis complex based on molecular and morphological markers. Evolution 58:324-337

Fukami H, Chen CA, Budd AF, Collins A, Wallace C, Chuang Y, Chen C, Dai C-F, Iwao K, Sheppard C, Knowlton N (2008) Mitochondrial and nuclear genes suggest that stony corals are monophyletic but most families of stony corals are not (order Scleractinia, class Anthozoa, phylum Cnidaria). PLoS ONE 3:e3222

Glynn PW (1974) Rolling stones among the Scleractinia: mobile coralliths in the Gulf of Panama. Proc 2nd Int. Coral Reef Symp 2:183-198

Gouy M, Guindon S, Gascuel O (2010) SeaView version 4: a multiplatform graphical user interface for sequence alignment and phylogenetic tree building. Mol Biol Evol 27:221-224

Heyward AJ (1985) Chromosomes of the coral Goniopora lobata (Anthozoa: Scleractinia). Heredity 55:269-271

Kitahara MV, Cairns SD, Stolarski J, Blair D, Miller DJ (2010) A comprehensive phylogenetic analysis of the Scleractinia (Cnidaria, Anthozoa) based on mitochondrial CO1 sequence data. PLoS ONE 5:e11490
Lewis JB (1989) Spherical growth in the Caribbean coral Siderastrea radians (Pallas) and its survival in disturbed habitats. Coral Reefs 7:161-167

Lin MF, Luzon KS, Licuanana WY, Ablan-Lagman MC, Chen CA (2011) Seventy-four universal primers for characterizing the complete mitochondrial genomes of scleractinian corals (Cnidaria; Anthosoa). Zool Stud 50:513-524

Milne Edwards H (1860) Histoire naturelle des Coralliaires ou polypes proprement dits, Tome troissème: suite de la section des Madréporaires apores. Roret, Paris

Milne Edwards H, Haime J (1851) Monographie des Polypiers fossiles des terrains Palaeozoïque. Arch Mus Hist Nat Paris 5:1-502

Murray J (1885) Report of the scientific results of the voyage of HMS Challenger during the years 1873-1876. Narrative Rep Sci Res Voy HMS Challenger 1:511-1110

Nemenzo F (1955) Systematic studies on Philippine shallow water scleractinians: I. Suborder Funngiida. Nat Appl Sci Bull 15:3-84, pl. 1-14

Nishihira M, Veron JEN (1995) Hermatypic corals of Japan. Kaiyusha, Tokyo (in Japanese)

Nylander JAA (2004) Mr.Modeltest v2. Program distributed by the author. Evolutionary Biology Centre, Uppsala University, Uppsala, Sweden

Oliver I, Beattie AJ (1996) Invertebrate morphospecies as surrogates for species: a case study. Conserv Biol 10:99-109

Ortmann A (1888) Studien über Systematik und geographische Verbreitung der Steinkorallen. Zool Jahrb Abt Syst Geogr Biol Tiere 3:143-188, pl. 6

Pichon M (1974) Free living scleractinian coral communities in the coral reefs of Madagascar. In: Proceedings of the Second International Coral Reef Symposium, vol 2. The Great Barrier Reef Committee, Brisbane, pp 173-182

Riegl B, Piller WE, Rasser M (1996) Rolling stones: first record of an Acropora anthocercis (Brook) corallith from the northern Red Sea. Coral Reefs 15:149-150

Romano SL, Cairns SD (2000) Molecular phylogenetic hypotheses for the evolution of scleractinian corals. Bull Mar Sci 67:1043-1068

Ronquist R, Huelsenbeck JP (2003) MRBAYES 3: Bayesian phylogenetic inference under mixed models. Bioinformatics 19:1572-1574

Rosen BRR, Taylor JD (1969) Reef coral from Aldabra: new mode of reproduction. Science 166:119-121

Scheer G (1960) Viviparie bei Steinkorallen. Naturwissenschaften 47:238-239

Scoffin TP, Stoddart DR, Tudhope AW, Woodroffe C (1985) Rhodoliths and coralliths of Muri Lagoon, Rarotonga, Cook Islands. Coral Reefs 4:71-80

Swofford DL (2002) Phylogenetic analysis using parsimony (* and other methods), version 4.0b10. Sinauer Associates, Sunderland, MA

Tribble GW, Randall RH (1986) A description of the high-latitude shallow water coral communities of Miyake-jima, Japan. Coral Reefs 4:151-159

Vaughan TW (1907) Some madreporarian corals from French Smaliland, East Africa, collected by Dr. Charles Gravier. Proc US Nat Mus 32:249-266, pl. 17-28

Veron JEN (1985) New Scleractinia from Australian coral reefs. Rec West Aust Mus 12:147-183

Veron JEN (1992) Hermatypic corals of Japan. Aust Inst Mar Sci Monogr Ser 9:1-234

Veron JEN (2000) Corals of the world. Australian Institute of Marine Science, Townsville

Veron JEN, Pichon M (1982) Scleractinia of eastern Australia, Part 4. Aust Inst Mar Sci Monogr Ser 5:1-159

Wei NWV, Wallace CC, Dai CF, Pillay KRM, Chen CA (2006) Analyses of the ribosomal internal transcribed spacers (ITS) and the 5.85 gene indicate that extremely high rDNA heterogeneity is a unique feature in the scleractinian coral genus Acropora (Scleractinia: Acroporidae). Zool Stud 45:404-418

Wells JW (1955) Recent and subfossil corals of Moreton Bay Queensland. Univ Queensl. Pap Dept Geol 4:1-18, pl. 1-3

Zwickl DJ (2006) Genetic algorithm approaches for the phylogenetic analysis of large biological sequence datasets under the maximum likelihood criterion. Dissertation, University of Texas, Austin

doi:10.1186/1810-522X-52-25

Cite this article as: Kitano et al: Phylogenetic and taxonomic status of the coral Goniopora stokesi and related species (Scleractinia: Poritidae) in Japan based on molecular and morphological data. Zoological Studies 2013 52:25. 